\title{
Funderinger over Abrahams offer \\ Fundamentalisme, mysterium og teleologisk suspensjon i Kierkegaards Frygt og Bæeven
}

\author{
MARIUS TIMMANN MJAALAND
}

F. ig7i. Dr. Theol., magister i filosofi. Postdoktor (NFR) Ved Det teologiske FAKUltet, UiO. Adr.: Det TeOlogiske FAKUltet, PB IO23 Blindern, O3I5 OSLO. E-Post: M.G.MJAALAND@TEOLOGI.UIO.NO

\begin{abstract}
Emmanuel Levinas has criticized Kierkegaard for doing «philosophy with a hammer», paving the way for that absurd suspension of the ethical under the rule of German National Socialism. Entering the 2Ist century, suicide bombers and religious fundamentalists make Abraham's sacrifice in Fear and Trembling

seem even more current, but also more problematic than ever. Basing his analysis of Kierkegaard on Derrida's Gift of Death, the author enters into the problem of sacrifice in its relation to faith, love, and responsibility in order to give a more nuanced analysis of modern fundamentalism.
\end{abstract}

Keywords

Sacrifice $\bullet$ Gift $\bullet$ Love $\bullet$ Responsibility

Abraham er en morder, hevder Johannes de Silentio i Frygt og Baeven, og det til tross for at han ikke stikker kniven i sønnen. Idet han løfter kniven over Isak med den hensikt å ofre ham, er han de jure en morder og etikken kan ikke dømme annerledes (SKS 4: 125-126). ${ }^{\mathrm{I}}$ Forfatteren fastholder likevel at morderen, Abraham, med rette kalles for «troens far» fordi han var ubetinget lydig mot Gud og var villig til å ta livet av sønnen. Dette er dilemmaet Frygt og Bæeven er skrevet over. Dette er det forferdelige som denne boken ikke kan skyve fra seg, men må dvele ved (jf. SKS 4: I44-I47). 
Spørsmålet er om en slik lesning av Abrahams ofring kan forsvares, dessuten om bruddet med etikken kan fastholdes som rasjonell - og i tilfelle ut fra hvilken forståelse av rasjonalitet. Dette fører igjen over i prinsipielle problemstillinger knyttet til forholdet mellom det allmenne ved språket og det uutsigelige som hører tausheten til, om forholdet mellom det absolutte og det relative og om muligheten for å trekke en grense mellom etikk og religion. Roe Fremstedal forsøkte i et tidligere nummer av NTT å forsvare Kierkegaard mot anklager om fundamentalisme, paternalisme og partikularisme (Fremstedal 2006). Et slikt forsvar er utvilsomt gjennomført med de beste intensjoner, men det er likevel ikke uproblematisk. Selve provokasjonen i en tekst som Frygt og Baeven ligger nemlig i den fundamentale og radikale lydighet Abraham handler etter - etter alt å dømme i konflikt med det allmenne ansvaret som hviler på ethvert menneske. Det er neppe mange som ville lese Kierkegaard dersom de fant en politisk korrekt rasjonalist. Den moralske indignasjonen hos kritikerne kan derfor i dette tilfelle nærmest oppfattes som et litterært kvalitetsstempel. Hele debatten kommer skjevt ut når den gode moral og den rene samvittighet oppheves til gyldighetskriterier for interessante problemstillinger (jf. Caputo I998).

Det fins imidlertid også forsøk på å problematisere Frygt og Bæeven som går i dybden av teksten og anerkjenner behovet for differensiering. To av de mest utfordrende finner vi hos filosofene Emmanuel Levinas og Jacques Derrida. De tar opp sentrale spørsmål i teksten, som offeret, etikken, ansvaret, det uutsigelige og det absurde, men uten å sikre sin egen tolkning i et forsvar for god moral. De diskuterer spørsmålene med lidenskap og kritisk distanse som politisk og filosofisk brennbare problemstillinger. Nettopp disse to vil stå sentralt i min analyse av Kierkegaard. Men før vi kommer til de franske fenomenologene vil jeg redegjøre for den rasjonalitetsdiskurs som spiller med i hele denne debatten og som ofte har skapt stor forvirring i brytningen mellom modernitet og postmodernitet.

\section{Fornuftskritikk: Innenfra eller utenfra?}

Spørsmålet om Kierkegaards rasjonalitet ble tatt opp i full bredde i NTT for omtrent et år siden, i nr. 2/o6. Roe Fremstedal trakk da frem en rekke innvendinger som har vært rettet mot Kierkegaard; at han er paternalistisk, fundamentalistisk og partikularistisk. ${ }^{2}$ Som utgangspunkt for diskusjonen presenterer Fremstedal det han anser for å være allment anerkjente definisjoner av begrepene fundamentalisme og paternalisme. Fundamentalisme dreier seg således om å stole på en absolutt autoritet og unndra seg argumentasjon og kritikk, illegitim paternalisme om en «intolerant praksis som ikke kan begrunnes eller rettferdiggiøres overfor andre», hvilket forsterkes 
av at ofringen angivelig fremstilles partikularistisk, som et «rent privat foretak». (Fremstedal 2006: 85-86) Fremstedal innrømmer at dette til dels er treffende beskrivelser av Abraham, men vil likevel søke å forsvare Kierkegaard mot anklagene. Han følger derfor en dobbelt strategi i sin vurdering av Kierkegaard-kritikken. Han innrømmer at i hvert fall paternalisme og intoleranse treffer Abraham, men ikke forfatteren av boken. ${ }^{3}$ Kierkegaard distanserer seg fra Abraham ved å skrive under pseudonymet Johannes de Silentio. ${ }^{4}$ Det som da skjer, er at Fremstedal faktisk gjør seg helt avhengig av rasjonaliteten hos de kritikerne han kritiserer, 5 i den forstand at han slår over i kritikkens dialektiske motsetning: Mot anklagen om fundamentalisme hevder han det diskursive, mot anklagen om paternalisme og individualisme peker han på at Kierkegaard andre steder vektlegger det intersubjektive og nestekjærligheten og mot det partikularistiske hevder han at Kierkegaards kjærlighetsbegrep innebærer «(...) at andre mennesker møtes med henholdsvis universell anerkjennelse og respekt.» (Fremstedal 2006: I02)

Det er mangler ikke på velvillig lesning av Kierkegaard, men Fremstedals fremste problem er at han overtar samtlige forutsetninger fra kritikerne og dermed frasier seg muligheten til å foreta en diskusjon om premissene - hvilket i dette tilfelle faktisk er Kierkegaards/de Silentios anliggende: Abrahams offer rokker ved premissene for en allmenn forståelse av etikken og en rasjonalistisk forståelse av det absolutte - og dessuten ved hegelianernes forsøk på spekulativt å «oppheve» enhver motsetning mellom fornuft og religion. Motspørsmålene blir derfor: Hva om Fremstedal her går i lengste laget i retning av et forsvar? Hva om han i sin iver over å gjøre Kierkegaard humanistisk og rasjonell lukker ham inne i den posisjon han angriper?

Fremstedals «reddende» kritikk av Kierkegaard illustrerer et dilemma som antagelig også Kierkegaard i sin tid har stått overfor: Idet man kritiserer en tenker, har man ofte en tendens til å havne i den motsatte posisjon, enten man så vil det eller ikke. Man gjør derfor klokt i å velge seg sine motstandere med omhu. Om Kierkegaards viktigste filosofiske motstander historisk betraktet var Hegel selv eller de danske hegelianere spiller i dette tilfelle liten rolle (contra Stewart 2003). Når Kierkegaard står overfor alternativene å kritisere Hegel og ende opp med en anti-hegelsk rasjonalitet eller å følge Hegel og innordne sin tenkning i det hegelske system, så svarer han i realiteten med et «verken - eller». Han motsetter seg dette valget. Hans agenda er nemlig en ganske annen enn Hegels og da er han nødt til å velge en tredje vei, som verken fører ut i det irrasjonelle eller inn i systemet. Denne tredje veien kan karakteriseres som en ironisk-polemisk distanse og innebærer blant annet retoriske strategier som pseudonymitet, genrebrudd, litterære plott og refleksjoner rundt det absurde. ${ }^{6}$ 
Frygt og Bæeven målbærer på disse særlige betingelsene en radikal form for fornuftskritikk. Med sikker sans for provokasjonen både i beretningen om Abraham og i «suspensjonen» av den allmenne etikk tar Søren Kierkegaard, under pseudonymet Johannes de Silentio, et oppgiør med det moderne opplysningsprosjektet og den tyske idealismen.7 Spørsmålet er imidlertid om verket av den grunn må kalles irrasjonelt eller enda verre, om Kierkegaard med rette kan anklages for moderne anathemata som fundamentalisme, paternalisme og partikularisme. Det kommer alt an på hvilken forståelse av rasjonalitet man refererer til. Johannes de Silentios fornuftskritikk er ikke et forsøk på en kritikk utenfra, altså fra en posisjon utenfor hhv. Kants kritiske prosjekt og Hegels spekulative system. Det er snarere en kritikk innenfra, ettersom de Silentio baserer hele sitt kritiske memento på Abraham, som kalles «troens far». Utgangspunktet er altså en sentral skikkelse og en avgjørende hendelse innenfor den teologiske og filosofiske tradisjon både Kant og Hegel er en del av og - om enn kritisk - slutter seg til. ${ }^{8}$

Beretningen om Abraham som ofrer sin sønn Isak er en beretning om det forferdelige, om et mysterium tremendum som er innskrevet i den jødisk-kristne tradisjon (jf. Derrida I995: 66-67). Rystelsen problematiserer imidlertid ikke bare den spekulative og den opplysningsfilosofiske rasjonalitet. Det skulle vise seg at den fortsatt virket rystende på det 20. århundres filosofi, ja kanskje mer rystende enn noen gang - på grunn av dette unevnelige offer som kan gjøre ethvert tenkende menneske språkløst. Når Levinas kritiserer Kierkegaard, så knytter han kritikken direkte til nasjonalsosialismens totale suspensjon av det etiske (Levinas I996: 76). Kierkegaard blir dessuten ofte trukket frem som en stråmann i oppgjøret med Heideggers forvikling med regimet.

Ser vi på de hendelser som har rystet verden ved inngangen til det 2I. århundre, så gjør de ikke boken mindre aktuell. Kanskje er det likevel nå, i lys av tolkningshistorien, mulig å nærme seg denne teksten noe mer nyansert uten at man derfor blir nødt til å forsvare den, enn si temme den, så den blir spiselig for enhver. ${ }^{9}$ Sett at Frygt og Bæeven - og for så vidt også filosofen og dikteren som står ansvarlig for den - skulle vise seg å uttrykke en form for fundamentalisme, men en tenkende sådan: Ville det ikke da være desto større grunn til å beskjeftige seg med nettopp denne teksten? Ville det ikke være en sjelden mulighet til bedre å forstå dette fenomen som i vår tid karakteriseres som religiøs fundamentalisme? Eller ville det bringe fundamentalismen altfor nær til vår egen tradisjon og kultur, slik at det ble vanskeligere å finne de riktige og entydige svarene?

Mitt utgangspunkt er at dette kun lar seg gjøre dersom man gir avkall på å skulle forsvare Kierkegaard mot anklagene. Om han er paternalistisk, så er han neppe den eneste filosofen i det I9. århundre som er det. Det er ingen grunn til å legge 
skjul på at han utrettelig vektla «hiin Enkelte» som sin kategori - og da blir det litt kunstig å kalle hans ansats «universalistisk». Likeledes får lidenskapen hos Kierkegaard iblant klare fundamentalistiske trekk, og disse trekkene er snarere tiltagende enn avtagende i forfatterskapet. En kan bare tenke på Øieblikks-striden. Men legger man en moderne forståelse av begrepet fundamentalisme til grunn, gjør man seg straks skyldig i en anakronisme.

I likhet med Johannes de Silentio skal jeg derfor ta utgangspunkt i en hegelsk forståelse av det allmenne, av språket og av forholdet mellom etikk og religion. I Frygt og Bæven kritiseres ikke denne utenfra, den problematiserer snarere innenfra ved at de Silentio (i) peker på en indre motsigelse i begrunnelsen av det etiske; (ii) avdekker en ubestemmelig tvetydighet i forholdet mellom språk og taushet, ved at samvittighetens hemmelighet i Abrahams tilfelle unndrar seg det allmenne språklige uttrykk (han kan ikke tale); og dessuten (iii) trekker et skille mellom en absolutt, religiøs begrunnelse av etikken og en relativ, «sedelig» begrunnelse, slik denne formuleres hos Hegel. Johannes avviser slett ikke etikkens allmenne gyldighet, men hevder at det religiøse innebærer en suspensjon av det etiske, dvs. en form for etisk unntakstilstand. Det er i en slik unntakstilstand problemene settes i perspektiv.

Emmanuel Levinas og Jacques Derrida er begge i en viss forstand fenomenologer, men formulerer hhv. en kritikk og en dekonstruksjon av det fenomenologiske prosjekt - i begge tilfelle dreier det seg altså om en rasjonalitetskritikk innenfra (evt. en forskyvning av forholdet mellom utenfor og innenfor, som i Derridas Grammatologi (Derrida i967a)). Levinas er i sin omtale av Frygt og Baven meget kritisk, men kan ellers uttale seg anerkjennende om Kierkegaards filosofi og er i visse henseende sterkt påvirket av denne (Westphal I995; Levinas I974: 2I4-215). Når det gjelder forholdet mellom Levinas og Derrida, så er Derrida sterkt kritisk til Levinas i en tidlig fase, men senere i sitt forfatterskap vektlegger han først og fremst det som forbinder de to. ${ }^{\mathrm{IO}}$ I Donner la mort (I992), som jeg her skal legge stor vekt på, gir han faktisk en tolkning av Frygt og Bceven som lar tekster av Kierkegaard og Levinas ligge tett opp til hverandre, men uten at forskjellene nivelleres. Sentralt i debatten står spørsmålet om offeret, om en etikk som springer ut av gavens økonomi og om språkets forhold til mysteriet. Alle disse problemstillingene skal jeg ta opp i det følgende, før jeg avslutningsvis vender tilbake til spørsmålet om fundamentalisme i Frygt og Boven.

\section{Levinas: Rystelsen og offeret}

La meg kort skissere problemstillingen i Frygt og Bævven. Etter å ha holdt sin lovtale over Abraham, formulerer Johannes de Silentio følgende rystende problemstilling: 
Hvoraf forklarer man en saadan Modsigelse som hiin Talers? Er det fordi Abraham har faaet Hævd paa at være en stor Mand, saa at hvad han gjør, er stort, og naar en Anden gjør det Samme, er det Synd, himmelraabende Synd? I saa Fald da ønsker jeg ikke at deeltage i slig tankeløs Lovprisen. Kan Troen ikke gjøre det til en hellig Handling at ville myrde sin Søn, saa lad den samme Dom gaae over Abraham som over enhver Anden. Mangler man maaskee Mod til at gjennemføre sin Tanke, at sige, at Abraham var en Morder, da er det vel bedre at erhverve dette Mod, end at spilde Tiden paa ufortjente Lovtaler. Det ethiske Udtryk for hvad Abraham gjorde er, at han vilde myrde Isaak, det religieuse er, at han vilde offre Isaak; men i denne Modsigelse ligger netop Angesten, der vel kan gjøre et Menneske søvnløst, og dog er Abraham ikke den, han er, uden denne Angst. (SKS 4: 125-126)

Kan så troen giøre det til en hellig handling å ville myrde sin egen sønn? Spørsmålet er ikke mindre aktuelt i dag enn for I 60 år siden, da dette med «hellig handling» snarere fremsto som hypotetisk, som gal manns verk. Kan den samme handling altså etisk fordømmes som et mord og likevel, religiøst, gjelde som et offer som er en lovtale verdig? Og har denne type problemstillinger gyldighet $i$ andre sammenhenger enn i spørsmålet om drap og offer? I noen grad allmenngjøres dilemmaet ved at Johannes de Silentio formulerer tre generelle problemer som står på spill $\mathrm{i}$ beretningen om hvordan Abraham går opp på fjellet Moriah for å ofre sønnen Isak:

Gives der en teleologisk Suspension af det Ethiske? Gives der en absolut Pligt mod Gud? Var det ethisk forsvarligt af Abraham, at han fortiede sit Forehavende for Sara, for Elieser, for Isak? (SKS 4: I48; I60; I72)

Så absurd det enn høres ut, opptok disse tre eksistensielle problemene Søren Kierkegaard av helt personlige grunner i perioden I84I-43. Dilemmaet, som i denne sammenheng virker temmelig uskyldig, var følgende: Var det forsvarlig av ham å bryte forlovelsen med Regine og dermed bryte ut av sin etiske forpliktelse til å leve et respektabelt liv som ansvarlig og pliktoppfyllende borger? ${ }^{\text {II }}$ Kierkegaard kan kun tenke seg to typer begrunnelse for et slikt brudd med det etiske per se. Enten en estetisk, dvs. han vil være dikter og gir en god dag i hva samfunnet forventer. Eller en religiøs, dvs. han kjenner en absolutt forpliktelse til å gjøre noe annet, ofre sitt liv som respektert samfunnsborger, ofre Regine og vie sitt liv til å skrive for om mulig å avdekke hva det betyr å være kristen, hva det kan bety dersom det viser seg at kirken og samfunnet omkring ham slett ikke har forstått det. Dette siste begrunnes med en teleologisk suspensjon av det etiske; det fins med andre ord en høyere, subjektiv grunn - et kall kunne man faktisk kalle det - som i en bestemt situasjon midlertidig opphever den allmenne etiske forpliktelse. Gjennom 
hele forfatterskapet fortsetter han å kretse omkring disse problemene, og det er en pine for ham at de ikke lar seg entydig avklare: Det som i det ene øyeblikk fremstår som et sentralt religiøst anliggende, mistenkes i neste øyeblikk for å springe ut av dikterens subjektive interesse og fantasi, hvorved han dikter Gud «en lille Smule annerledes end Gud er» (SKS Ir: 192).

Den teleologiske suspensjon i Frygt og Bæven blir imidlertid innført i et forsøk på å etablere et klart skille mellom det etiske og det religiøse: Det religiøse begrunnes annerledes enn det etiske, som en absolutt forpliktelse overfor det absolutte og denne absolutte forpliktelse kan man i en viss forstand ikke giøre rede for, fordi den bryter med forstanden, med den allmenne begrunnelse for hvorfor man handler slik man gjør (SKS 4: I62). Man er nødt til å bære begrunnelsen i taushet, noe som gir offeret dobbelt tyngde: Ikke bare ofrer man det kjæreste man eier, man ofrer også muligheten for umiddelbart å kunne forklare seg til sine nærmeste; man er absolutt ensom med sin forferdelige hemmelighet - og kan ikke meddele seg annet enn indirekte (SKS 4: 2OI).

Akkurat på dette punktet, ved overgangen mellom det første og det andre dilemmaet, setter imidlertid Emmanuel Levinas' kritikk inn. Kritikken gjelder Johannes de Silentios åpning for det religiøse absolutthetskrav innenfor etikkens domene. Også Levinas vil trekke et skille mellom det etiske og det religiøse, men kun for å gi etikken en ikke-religiøs fundering. Han betrakter etikken som «første filosofi» som verken lar seg nivellere av en abstrakt værens-metafysikk eller overstyre av religiøse unntak, som i Abrahams tilfelle. Verken et politisk, totalitært regime eller en monoteistisk religion skal tillates å stille absolutthetskrav som bryter med den etiske forpliktelse som enhver burde være forpliktet på. Levinas går faktisk så langt at han anklager Kierkegaards brudd med det etiske for å legge veien fri for Nietzsche, for Heidegger og i siste instans for nasjonalsosialismen, ${ }^{\mathrm{I} 2}$ for dette unevnelige:

\footnotetext{
It is Kierkegaard's violence that shocks me. The manner of the strong and the violent, who fear neither scandal nor destruction, has become, since Kierkegaard and before Nietzsche, a manner of philosophy. One philosophizes with a hammer. In that permanent scandal, in that opposition to everything, I perceive by anticipation the echoes of certain cases of verbal violence that claimed to be schools of thought, and pure ones at that. I am thinking not only of National Socialism, but of all the sorts of thought it exalted. That harshness of Kierkegaard emerges at the exact moment when he «transcends ethics.» (Levinas I996: 76)
}

Ifølge Levinas fins det ingen absolutt instans utenfor det menneskelige fellesskap som kan legitimere et brudd med det etiske. Tvert imot er det slik at det absolutt annet - Gud - viser seg i møtet med den annens ansikt og bare der. 
På den annen side taler også Levinas om et offer, nemlig et offer som kan være nødvendig i møte med den annens ansikt. ${ }^{13}$ Også han trekker frem Abraham, men legger vekt på andre sider ved beretningen: For det første at Abraham lyttet til Gud da Gud kalte ham tilbake fra villfarelsen om å skulle drepe sønnen, tilbake til etikkens orden. For det andre peker han på at Abraham var villig til å ofre seg selv da han gikk i forbønn for de rettferdige i Sodoma og Gomorra - før utslettelsen (Levinas I996: 77). Dette å vende tilbake til etikkens orden, men innenfor etikkens orden å være villig til offer, tenker Levinas som en radikal etisk forpliktelse: Stilt overfor den annens død vil enhver kunne bli nødt til å ofre seg selv. Dette er det etiske krav som kommer til syne i den annens ansikt. Nettopp i en slik forståelse av etikken, der man ikke sparer seg selv, men oppdager tilværelsens mening og finner sin identitet i møtet med den annens ansikt, hevder Levinas at også det religiøse kommer til syne.

\section{Derrida: Tout autre est tout autre}

I essayet Donner la mort fra $1992^{\text {I4 }}$, i engelsk oversettelse The Gift of Death (I995), tar Jacques Derrida opp begge disse analysene av offeret som fremstår som diametralt motsatte; Kierkegaards og Levinas'. De to har totalt forskjellige oppfatninger av forholdet mellom det etiske og det religiøse, av Abraham, av offerets betydning. Men Derrida fastholder at det fins en vesentlig innsikt om forholdet mellom etikk og religion, om den enkelte og det allmenne, både hos Kierkegaard og Levinas. Han motsetter seg derfor valget mellom de to, som et enten-eller. Tvert imot leser han de to filosofene parallelt, med utgangspunkt i et oksymoron eller en såkalt shibboleth. 'Shibboleth' er hebraisk og anvendes av Derrida om et uttrykk eller en setning som i et bestemt språk får (minst) dobbelt betydning - og der denne dobbelthet eller flertydighet nettopp er det interessante med selve uttrykket, i den forstand at måten det leses på, feller en dom over leseren selv. ${ }^{15}$ Derridas shibboleth er i denne sammenheng det franske uttrykket Tout autre est tout autre (Derrida I995: 68). Enhver annen er helt annerledes. Eller: enhver annen er alt annet. Eller: det helt andre er helt annerledes, osv. Det som i utgangspunktet ser ut som en tautologi, åpner for en rekke ulike betydninger og lesninger.

Den første lesningen Derrida foretar, svarer til det vi kan kalle en klassisk lesning av Frygt og Bæeven. For 'tout autre' setter han inn 'Dieu' - altså Gud. Det gir lesningen «Gud er helt annerledes» (Derrida I995: 66-74). Følgelig er det god grunn til å giøre som Kierkegaard/ de Silentio, nemlig å sette et klart skille mellom det etiske og det religiøse, ettersom han oppfatter Gud som så totalt annerledes og Guds veier som så uransakelige at de krever et brudd med det etiske og det allmenne. 
Men dernest vrir Derrida uttrykket i en annen retning, nemlig: enhver annen er helt annerledes - likesom Gud er helt annerledes. Ethvert menneske, selv ethvert dyr, er ikke bare unikt, men også så annerledes enn meg at han/hun/det fortjener absolutt ærefrykt og respekt - slik Gud gjør det (Derrida I995: 77-78). Abrahams dilemma blir med andre ord innskrevet i de mest alminnelige situasjoner. Enhver annen er helt annen - tout autre est tout autre - og den alteritet som åpner en skremmende avgrunn mellom meg og Gud, et mysterium tremendum, åpner en tilsvarende avgrunn mellom meg og enhver annen, menneske eller dyr. Det er overfor en slik alteritet jeg stilles til ansvar, og det er denne annen jeg ofrer hver gang jeg ofrer hensynet til ett menneske fremfor hensynet til et annet (Derrida I995: 87). Derrida bruker de sultne og de hjemløse som eksempel. Disse ofres hver dag til fordel for mennesker som står en nærmere (Derrida I995: 86). Men det kan like gjerne være de aller nærmeste, ens egen familie, som ofres til fordel for en selv eller andre mennesker, saker, formål, et annet telos. Men for enhver annen er ansvaret gitt meg som ubetinget ansvar. Dette følger av en opprinnelig absolutt ansvarlighet overfor alt og alle - eller som fader Sosima uttrykker det i Brødrene Karamasov: Vi er alle skyldige i alt for alle, og jeg mer enn noen annen.

Lest på denne andre måten uttrykker faktisk Kierkegaards tekst noe av det samme eller i det minste et tilsvarende ansvar som det Levinas tar til orde for (jf. Derrida I995: 84) - og jeg mener at dette slett ikke er noen urimelig eller dårlig lesning av Frygt og Bæeven. Den plasserer nemlig det religiøse ansvar innenfor den etiske horisont, hva Kierkegaard i senere tekster beskriver som det etisk-religiøse eller den annen etikk. Dette innebærer en radikalisering av det etiske ansvar, både i den forstand at det får ubetinget gyldighet for ethvert annet menneske, også for den fremmede (jf. Luk Io, 25-37; Matt 5, 43-45), og i den forstand at man om nødvendig er kalt til å ofre seg selv og sin kjærlighet til seg selv for kjærligheten til den annen; dvs. at kjærligheten til den annen er det som begrunner og gir dybde også til budet om å elske seg selv - som sin neste. ${ }^{16}$

I begge disse forhold inntrer Gud som en mellombestemmelse mellom selvet og den annen (Sml. SKS 9: III). På samme måte inntrer ens neste som mellombestemmelse mellom en selv og Gud - hvilket forhindrer enhver abstrakt forståelse av gudsforholdet: Den annen er alltid prøvesteinen på om det er Gud en forholder seg til eller en abstrakt idé om guddommen (Sml. SKS 9: I44). Og dermed åpner avgrunnen seg - denne frykt og beven - mellom selvet og ethvert annet menneske. Nærmest det eneste som vi må lete forgjeves etter hos Kierkegaard, er den rørende omsorg for dyrene som Derrida gir uttrykk for.

Derrida hevder at det både hos Levinas og Kierkegaard oppstår en avgjørende sammenheng mellom det etiske og det religiøse. Begge introduserer riktignok et 
skille, for dernest å markere skillets betydning ved kontrasten mellom det etiske og det religiøse. Men ser vi på problemstillingen hos Kierkegaard, så er den primært av etisk karakter. Likefullt spiller altså det religiøse inn og forstyrrer etikkens autonomi, ja den religiøse suspensjon av etikken setter hele etikken og dens forventning om gjensidig forpliktelse på spill. Ansvaret begrunnes i stedet i en direkte ansvarlighet overfor Gud, som ikke kan reduseres til et moralsk system av Sittlichkeit. Ansvaret settes på prøve i den situasjonen der reglene suspenderes og hver enkelt står der med sin tro, sin plikt, sin kjærlighet og sin dømmekraft. Kierkegaard peker ganske riktig på at en slik situasjon setter hele etikkens fundament på spill. Abraham bryter ut av etikkens orden. Men samtidig er refleksjonen dypt etisk, da han i sin fortvilelse søker en dypere fundering for etikken i Guds påbud om å ofre. Offersituasjonen stiller ham på grensen, ja, problematiserer selve grensen mellom etikk og religion. Han vil verken ofre sin Gud eller sin sønn, men valget mellom de to synes uunngålig. Han bøyer seg og er villig til å ofre, han resignerer. Men han bevarer et absurd og fortvilet håp om å få sønnen tilbake i dette liv. Og i denne andre bevegelsen mot forstanden ser Kierkegaard/de Silentio et uttrykk for tro: Det absolutte kan ikke forstås metafysisk eller rasjonelt. Det må forutsettes som absolutt ansvarliggjørende, men kan kun erkjennes i sporet, i resignasjonen og i tilliten. Dermed innskrives etikken og det etiske ansvar i den uendelige religiøse dobbeltbevegelsen. Det etiske system bryter sammen, det rystes i sine grunnvoller, men gjeninnsettes med samme absolutte gyldighet idet engelen viser seg og Abraham får sin sønn tilbake. Han er imidlertid ikke lenger sin egen herre, hans etikk mangler et klart definert fundament. Fundamentet forsvinner i mysteriets avgrunn og erstattes kun av Abrahams tause tillit til Guds godhet - om nødvendig på tross av forstanden. Men dette er en godhet hinsides meddelelse, hinsides fornuftig tale (logos) og logikk.

Heller ikke Levinas avviser det religiøse per se, men han avviser dets relevans for etikken. Det han frykter er nettopp det ikke-rasjonelle bruddet med etikken som fremkommer i Kierkegaards analyse av Abraham. Levinas' alternative løsning er å trekke et enda tydeliger skille mellom det etiske og det religiøse. Men samtidig får etikken en annen begrunnelse enn i Hegels borgerlige Sittlichkeit. Han insisterer på at det er i ansiktet vi møter det annet menneske, det er der vi møter det annet overhodet. Ansiktet bestemmer oss først og fremst som etiske individer. Det religiøse vil alltid være sekundært i forhold til den virkelighet og den fordring som møter oss i ansiktet.

Levinas' skille blir således et utelukkelsesskille, mens Kierkegaards skille etablerer en krisis, et kontinuerlig skandalon. Ved å sammenholde disse to innenfor en og samme shibboleth hevder imidlertid Derrida et tredje standpunkt, der han 
(a) aksepterer etikkens menneskelighet, men også (b) Guds absolutte alteritet og annerledeshet og denne alteritets relevans for etikken. Han nekter å renonsere på ett av disse perspektivene for å gi det annet forrang. Således finner vi innenfor Derridas tekst to ulike måter å forstå etikken på, som strengt tatt er diametrale motsetninger. Og slike motsatte tolkninger av den etiske fordringen står på spill hver gang man handler eller skulle ha handlet og handlingen får etisk relevans: Kierkegaards med offeret av sønnen, Levinas' med offeret av en selv for den annen. I den grad dette dreier seg om etikken qua etikk, er den preget av dødens alvor og dødens avgjørelse: Med utgangspunkt i offeret blir døden stående i skjæringsfeltet mellom meg og den annen - det er livet og døden som står på spill; min egen død så vel som den annens død. Men også døden unndrar seg en entydig rasjonell bestemmelse. Døden er avgjørende, absolutt avgjørende, men unndrar seg fornuftens kontroll.

Fra dødens posisjon reflekterer Derrida omkring både Kierkegaard og Levinas, som to brennpunkter i diskursens ellipse, men uten å slutte seg til noen av dem. Dvs. han fastholder både Kierkegaards og Levinas' refleksjoner over offeret, forutsatt at begge springer ut av den samme shibboleth: Tout autre est tout autre. Det er en setning som forbinder og setter skille. Den åpner et rom mellom de to lesningene av Frygt og Bæeven som lar to fortolkninger bli stående overfor hverandre uten at forskjellene oppheves, uten at den ene fortolkningen erstatter den andre (Derrida I995: 84).

Denne forskjellen, dette irredusible skillet, uttrykker hva Derrida allerede tidlig i sine tekster gav betegnelsen différance - en forskjell som ikke oppheves, som ikke kan forklares, en forskjell som selv forblir skjult, men likefullt ligger til grunn for enhver betydning, enhver fortolkning av tekster eller fenomener. ${ }^{17}$ Også innenfor etikken er det en slik ubestemmelig differens som blir opphavet til menneskets ansvarlighet - og innenfor religionen til en bestemt form for negativ teologi (Derrida I995: 84-86). Det som viser seg og som beskrives av fenomenologien, etikken og religionene, går således tilbake på en forskjell som skjuler seg, som kun kommer til syne i sporet av noe annet, i sporet av det annet. Mellom de to lesningene oppstår ikke bare en meningsforskyvning, men også en tidsforskyvning, en kronisk utsettelse av den endelige forklaringen. Derrida motsetter seg for enhver pris å løse opp fortolkningen i en sammenfallende og enhetlig lesning, en Aufhebung av motsetninger, et absolutt nærvær. Fraværet av endelig forklaring innebærer at løsningen utsettes, mens ansvaret intensiveres; handlingen kan ikke vente til det foreligger et resultat og etikk dreier seg ikke primært om å følge den allmenne regel, men om ikke å unndra seg ansvaret for den annen: 
If I obey my duty towards God (which is my absolute duty) only in terms of duty, I am not fulfilling my relation to God. In order to fulfil my duty towards God, I must not act out of duty, by means of that form of generality that can always be mediated and communicated and that is called duty. The absolute duty that binds me to God, must function beyond and against any duty I have. (Derrida I995: 63)

Etikken kan være så korrekt og konsistent den bare vil, men den vil også være et redskap for å gjøre det etiske ansvaret rasjonelt og forutsigbart, dvs. holde etikkens krav innenfor rimelighetens grenser. Men det problem Kierkegaard reiser er at Abraham sprenger rimelighetens forutsigbare grenser.

Også Kierkegaards/de Silentios lesning av Abrahams offer baserer seg på noen særlige forutsetninger. Problemstillingen er genuint kristen idet den ser Guds ofring av sin sønn, Menneskesønnen, som utgangspunktet for en kristen etikk. Dette innebærer i neste omgang en internalisering av offeret, en internalisering som giør offeret mindre blodig, men fastholder konflikten mellom gjensidighetens etikk og villigheten til offer innenfor kjærlighetens diskurs. De Silentio vier en hel seksjon til å diskutere hvorvidt det kan være nødvendig i kjærlighetens navn å hate sin far og sin mor. Er dette hat et uttrykk for at kjærligheten krever offer? Vil enhver sann kjærlighet kreve denne type offer, på egne og andres vegne?

Det er i høy grad en forskjell mellom å ofre seg selv, slik Levinas tar til orde for, og å ofre en annen, slik Derrida og Kierkegaard hevder i visse situasjoner er uunngåelig. Men Kierkegaards egen situasjon - der han ser seg nødt til å ofre Regine og kjærligheten til henne for kjærligheten til Gud - illustrerer hvordan offeret som etisk problemstilling ikke alltid lar seg begrense til det ene eller det andre. Offerdiskursen er ikke en diskurs for den rene og ubesværede samvittighet, det er en diskurs som setter fokus på dilemmaene, ikke sjelden de helt uløselige dilemmaene i skjæringsfeltet mellom etikk og religion. Forventningen om å skulle oppfylle det umulige krav til kjærlighet, for eksempel Bergprekenens krav til fiendekjærlighet og fullkommenhet, fører ifølge Kierkegaard også til offer - $\mathrm{i}$ blant er det paradoksalt nok nettopp gjennom offeret kjærligheten finner sitt uttrykk. Og dette er motsigelsen, det er dette som unndrar seg den allmenne språklige virkelighetsbeskrivelse. Derfor dreier det seg ikke om en «universell» etikk til tross for at den er allmenn i den forstand at det kan gjelde enhver. Og her viderefører Derrida en kierkegaardsk tanke: Situasjonen setter den enkelte over det allmenne og det er i slike situasjoner en er kalt til å handle (Derrida I995: I08-I09). I likhet med Kierkegaard insisterer Derrida på at det fins slike unntagelser som gjør det nødvendig å sprenge det allmenne, ja, han spiller unntagelsens logikk inn i enhver situasjon, som muligheten til å handle annerledes, men fastholder derfor også det ansvar som på grunn av denne muligheten føres tilbake på den enkelte (Derrida I995: 
67). Dette ansvaret kan man selvfølgelig forsøke å unndra seg, men det forsvinner ikke. Den annen forsvinner aldri.

Er det én filosof som med tyngde har hevdet ansvaret for den annen, så er det nettopp Levinas. Den annens ansikt ser han (i dets annethet og annerledeshet) som en etisk fordring til enhver - men han motsetter seg påstanden om at dette bryter med etikken. Fremfor å fravike den etiske orden foretrekker han å lese det religiøse - også sporet av Gud som den annen - innenfor etikkens horisont (Levinas I996: 77). Det er således ingen grunn til å oppheve forskjellen mellom Kierkegaard og Levinas. Men Derrida viser at fordi begge fastholder en spenning mellom det etiske og det religiøse er det mulig å lese de to opp mot hverandre med utgangspunkt i selve spenningen og i den irredusible forskjellen mellom Kierkegaard og Levinas. Det etiske er allerede innskrevet i det religiøse og kan ikke løsrives fra en religiøs forståelse av annethet. Samtidig innebærer dette en radikalisering av etikken som stiller den enkelte til ansvar og således etablerer nødvendigheten av et ansvarlig selv som $i$ selvforholdet forholder seg absolutt til den/det annet. Det er en gjensidig avhengighet her, som gjør at diskursen ikke kan avsluttes eller oppheves. Derrida understreker at hensikten med en slik refleksjon over offeret er for enhver pris å forstyrre og uroe den gode samvittighet - à tout prix d'éviter la bonne conscience.

\section{Utskillelsens mysterium (le sécret du sécret)}

Derridas etikk kretser rundt to heterogene utgangspunkt for gavens fenomenologi: (i) Gaven som kulturell konvensjon, som knytter bånd mellom mennesker, som giør giver og mottaker avhengige av hverandre og primært tjener egennytten og (ii) gaven som ubetinget relasjon, som betingelsesløs gave uten mulighet for å gi tilbake (se Derrida I986). Den ubetingede eller fullkomne gaven er kanskje uoppnåelig, men likevel innskrevet $\mathrm{i}$ enhver gave som finner sted i relasjonen mellom to mennesker. Og døden som gave står her i en særstilling: Om noen ofrer sitt liv - og således gir sin død som gave - slik Sokrates gjorde det, slik Kristus gjorde det og andre har gjort det siden, fins det ikke lenger noen umiddelbar mulighet for å gi tilbake. En kan ikke annet enn å ta imot. I denne forstand svarer døden som gave til det ubetingede. Men som ubetinget unndrar den seg også en entydig bestemmelse, den er ikke tilgjengelig som «fenomen». Dødens betydning kommer til syne i en revne, i et spor, også når døden får karakter av gave i forholdet mellom et menneske og et annet.

Et overveldende eksempel på dette er nettopp Jesu død, som står helt sentralt ikke bare i kristen teologi, men i kulturer som er preget av kristen tenkning, ja i 
en verden som domineres av europeisk historie, jus, litteratur, filosofi og politikk. Jesu død knyttes av Derrida til et vendepunkt i ansvarlighetens historie. Selve historiebegrepet (også for den såkalt «sekulære» historie) knytter faktisk an til begrepene ansvar, tro og gave:

History can neither be a decidable object nor a totality capable of being mastered, precisely because it is tied to responsibility, to faith, and to the gift. To responsibility in the experience of absolute decisions made outside of knowledge or given norms, made therefore through the very ordeal of the undecidable; to religious faith through a form of involvement with the other that is a venture into absolute risk, beyond knowledge and certainty; to the gift and to the gift of death that puts me into relation with the transcendence of the other, with God as selfless goodness, and that gives me what it gives me through a new experience of death. Responsibility and faith go together, however paradoxical that may seem to some, and both should, in the same moment, exceed mastery and knowledge. The gift of death would be this marriage of responsibility and faith. History depends on such an excessive beginning [ouverture]. (Derrida I995: 5-6)

Både definisjonen av tro som «absolutt risiko, hinsides kunnskap og visshet» og av dødens gave som setter en i forhold til den annens transcendens, til Gud som uselvisk godhet, er verdt å legge merke til. Men det er først gjennom «ekteskapet» mellom ansvarlighet og tro at dødens gave etablerer det avgiørende vendepunkt $\mathrm{i}$ Derridas forståelse av historien - etablert gjennom en nylesning av Jan Patočkas Kjetterske studier i historiens filosofi (Patočka 1979). Han legger vekt på ansvarets avgjørelse, som ikke kan gjøres tilstrekkelig rede for gjennom ens kunnskap og ens overtatte etiske normer. Er ikke dette et paradoks, at avgjørelsen ikke kan begrunnes i normer, men likevel skal begrunne ansvaret? Er det ikke nærmest en oppskrift på anarki og moralsk vilkårlighet? Snarere tvert imot, hevder Derrida. Det er dette som forhindrer den sedvanlige ansvarsfraskrivelsen, der man unndrar seg ansvaret med henvisning til den etiske norm. I motsetning til den normbaserte handling vil avgjørelsen skille ut den enkelte som enkelt og giøre det umulig å unndra seg ansvaret, til tross for at en ikke fullt ut rasjonelt kan redegjøre for grunner.

I denne ansvarlighetens historie eller genealogi spiller beretningen om Abraham en sentral rolle, med dens gudsforestilling, ofringen og konflikten mellom det etisk allmenne og det absolutte guddommelige krav om lydighet. Dette kravet er imidlertid nettopp ikke tilgjengelig som et såkalt «absolutt bevissthetsfaktum», hva forfatteren de Silentio enn måtte mene med det. ${ }^{18}$ Kravet er mottatt som en absolutt fordring av Gud («Gud kalte...»), men giveren skjuler sin intensjon, ja faktisk er denne Guds skjulthet en nødvendig forutsetning for at fordringen er absolutt og gyldig for enhver. Den er ikke nivellert inn i systemet av andre (mer eller 
mindre relative) menneskelige fordringer, den synes tvert imot å representere en forstyrrelse og en suspensjon av det etiske per se. En slik forstyrrelse vil alltid måtte være en anfektet forstyrrelse, en fordring som vekker tvil, og hvis den ikke er det, er den eo ipso uansvarlig. Hele boken Frygt og Baven dreier seg nettopp om dette, om Abrahams rådvillhet, angst og tvil på veien opp mot Morija Berg. Johannes de Silentio skriver: «Det man udelader af Abrahams Historie er Angesten; thi mod Penge har jeg ingen ethisk Forpligtelse, men mod Sønnen har Faderen den høieste og helligste. Dog Angest er en farlig Sag for Blødagtige, derfor glemmer man den, og desuagtet vil man tale om Abraham.» (SKS 4: I24)

Kierkegaard skriver innenfor det moderne, han kjenner selvfølgelig Kants krav om å avvise Guds kall dersom kallet skulle stride med det kategoriske imperativ. Innenfor en moderne horisont vil tvilen altså omfatte berettigelsen til overhodet å forholde seg til Guds kall som absolutt. Hvordan kan han vite at det er Gud og ikke en djevel, enn si hans eget mørke indre som kaller på ham? Kan han vite dette? Og hvis ikke, er han ikke i så fall nødt til å avvise en slik problemstilling per se?

I all sin modernitet har denne problemstillingen også noe anakronistisk over seg. Den plasserer Abraham inn i vår tid og dømmer ham etter den praktiske fornufts «universelle» standard fra slutten av det I8. århundre. Abraham har ifølge Kierkegaard tvilt på mye, også hans gudsbilde har blitt rystet, men han har ikke tvilt på Guds autoritet og Guds kall til å ofre. Kants logikk blir, når den anvendes på Abraham, et påskudd til å avvise problemstillingen per se, dvs. fornuftens påskudd til å hevde sin uanfektede suverenitet også i etiske spørsmål. Det er denne suverenitet Johannes de Silentio destabiliserer i Frygt og Baven. Ikke ved å hevde at Abrahams offer skal gjentas på samme blodige måte som hos Abraham - det er både religiøst og etisk utillatelig - men ved å hevde at offeret og ofringens dilemma fortsatt befinner seg i hjertet av etikken og som sådan problematiserer den praktiske fornuft innenfra. Spørsmålet om gjentagelsen, som spilles ut flere ganger i Frygt og Bæeven er et spørsmål om hvilken annen betydning offeret får, hvilken grunnleggende betydning det får for tro og etikk, idet offeret som religiøs institusjon for lengst er avskaffet. Johannes de Silentio bevarer i og for seg denne historiske distanse til Abraham, men skildrer likefullt hans dilemma så realistisk som mulig fordi dilemmaet forblir like uløselig under andre historiske, etiske og religiøse betingelser.

Det kall som innbefatter det umulige, kallet til å ofre Isak, er kun mulig å fremstille i paradoksets form: den rettskafne som giøres til morder, den ufravikelige kjærlighet som tvinger ham til å gjøre det mest brutale offer. ${ }^{19}$ Johannes de Silentio insisterer på dette, at Abraham er uten svik i sin kjærlighet til sønnen og til Gud, men likevel (eller nettopp derfor) er han nødt til å gå den lange veien, gå til 
det fryktelige skritt å skulle fullbyrde offeret. Han vet ikke utfallet, han kan ikke forstå eller utgrunne noen forklaring på hvorfor - derfor er han nødt til å tie. Selv når han taler, tier han når Isak spør ham om hvor offerlammet er:

Så tok Abraham offerveden og la den på Isak, sønnen sin. Selv tok han ilden og kniven i hånden; og så gikk de sammen, de to. Da sa Isak til sin far Abraham: «Du far!» Og han svarte: «Ja, gutten min.» Isak sa: «Se, her er ilden og veden, men hvor er lammet som vi skal ofre?» Abraham svarte: «Gud vil nok selv se seg ut et offerlam, gutten min.» Og så gikk de videre sammen, de to. (Gen 22: 6-8)

Abraham svarer Isak, altså er han ikke taus. Men han svarer uten å svare: Gud vil nok se seg ut et offerlam, gutten min. Når han taler uten å tale, bevarer han hemmeligheten, subjektets og ansvarets hemmelighet. I sin analyse av Abrahams offer peker Derrida på at ordet hemmelighet har et dobbelt opphav i Vestens religions- og filosofihistorie. Det springer både ut av det latinske 'secretum', som betyr adskilt eller utskilt og av det greske 'mysterion' som betyr uforklarlig, skjult (lat. 'absconditum), utilgjengelig (Derrida I995: 89-9I). For å kunne handle ansvarlig må Abraham bevare hemmeligheten som offeret springer ut av: Hemmeligheten som skiller Abraham ut fra fellesskapet, skiller ham ut som enkeltperson i motsetning til alle de andre, og nettopp denne utskillelsen er uttrykk for den latinske siden ved hemmeligheten; secretum, secret, sekret - spytt eller utskillelse. Abraham er utskilt fra hele verden, for han kan ikke tale:

\footnotetext{
Abraham tier - men han kan ikke tale, deri ligger Nøden og Angsten. Naar jeg nemlig, idet jeg taler, ikke kan gjøre mig forstaaelig, saa taler jeg ikke, om jeg end talte uafbrudt Nat og Dag. Dette er Abrahams Tilfælde. Han kan sige Alt; men Eet kan han ikke sige, og dog naar han ikke kan sige det d.v.s. sige det saaledes, at en Anden forstaaer det, saa taler han ikke. Det lindrende i Talen er, at den oversætter mig i det Almene. Abraham kan nu sige det Skjønneste, noget Sprog kan opdrive, om hvorledes han elsker Isaak. Men dette er ikke det, der ligger ham paa Sinde, det er det Dybere, at han vil offre ham, fordi det er en Prøvelse. (SKS 4: 2OI)
}

Det som gjør tausheten til et mysterium tremendum er ikke i og for seg kjærligheten, heller ikke offeret per se, men konflikten mellom dem, som ikke kan formidles allment. Denne hemmeligheten må føres tilbake på avgrunnen i Abrahams gudsforhold, som Derrida utleder av det greske mysterion: Det er det uforklarlige, det skjulte, et mørke forut for alt lys, det mørke der lysets kilde skjuler seg før det trer frem, forut for enhver åpenbaring eller forklaring. Abrahams grunner for å skulle ofre Isak skjuler seg bak dette hemmelige og dette hellige, dette mysterium tremendum som vesentlig hører tausheten til, i frykt og beven. 
En slik taushet omgir i siste instans alle de problemene som her trekkes frem og trekkes inn i en filosofisk overveielse: Tausheten omgir døden og forsøket på å tenke døden, ens egen død så vel som den annens død. Tausheten omgir Gud, den Gud som er skjult og ser i det skjulte, forut for menneskets blikk, som selv unndrar seg blikket, som unndrar seg enhver fenomenologi, men som likevel møter mennesket i skjelvingen foran offeret - og i kjærlighetens skjelving overfor den annen (Derrida I995: 65-66). Ikke den brutale konflikten rundt offeret av sønnen (som er «økonomisk» i den forstand at den er innskrevet i gammeltestamentlig offerpraksis som alminnelig regulering av forholdet mellom mennesker og Gud), men den Gud som ser i det skjulte og likevel unndrar seg blikket, den Gud som stiller til ansvar overfor døden og holder ansvarlig for den annens død, er det Derrida forsøker å beskrive. I denne strategien ligger det en passiv motstand mot ønsket om kontroll over Guds navn (og $i$ Guds navn over den annen), enten ved at en hellig tekst leses som en etisk regelbok eller som evighetens regnskapsføring med henblikk på det hinsidige (jf. Derrida I995: 96-IOI).

\section{Fundamentalisme, offer, kjærlighet}

Gavens økonomi er et utgangspunkt for å analysere tre fenomener som krysser hverandre i Kierkegaards beskrivelse av Abraham i Frygt og Bøeven: Fundamentalismen, offeret og kjærligheten. De krysser hverandre i kjærlighetens offer, i ofringens ubetingede lydighet og i forståelsen av kjærlighetens opphav eller fundament. Ofte vil en forsøke en å skille disse fra hverandre, slik at fundamentalismen kan fordømmes så entydig som mulig, mens kjærligheten lovprises og offeret $\mathrm{i}$ beste fall glemmes eller neglisjeres.

Straks en trekker inn fundamentalismen i denne diskursen, får den imidlertid igjen noe anakronistisk over seg. Ordets moderne betydning stammer fra USA i tiden etter første verdenskrig, der «fundamentalism» ble brukt om grupper av kristne som ville ta Bibelens ord bokstavelig som verbalinspirasjon, det som siden er kalt biblisisme. For dem gjaldt ikke Bibelens ord bare i religiøse spørsmål, men også som politisk program. Fundamentalisme er således et moderne fenomen, en motreaksjon mot et liberalt og sekularistisk samfunn. ${ }^{20}$ Derfor er det også et fenomen som bærer mange av modernitetens kjennetegn, som en (tros)positivistisk rasjonalitet og en tendens til å søke totale - eller totalitære - løsninger på komplekse problemer. Etter andre verdenskrig har «fundamentalisme» så blitt brukt som betegnelse også på hinduiske og muslimske politiske bevegelser som søker tilbake til hellige skrifter og arbeider politisk-religiøst for en bekjempelse av bestemte tendenser $i$ et moderne samfunn. ${ }^{2 \mathrm{I}}$ 
Enkelte av dem er reaksjonære, men i aksjonsform og ideologi ofte høyst moderne - en kan bare tenke på en gruppering som det globaliserte og teknologisk avanserte nettverket Al-Qa'ida, hvis navn også henspiller på selve fundamentet, basisen for islamsk tro.

Det er nettopp i den sistnevnte betydningen jeg her vil trekke inn fundamentalismen som fenomen; muslimske grupperinger som kalles fundamentalistiske knyttes til bruk av menneskeoffer i en politisk og religiøs kamp, i form av selvmordsbomber eller andre terroraksjoner. Dette er, for å trekke en parallell til Frygt og Bæeven, ikke mord eller hellig handling. Det er mord og hellig handling. Det er en helliggiøring av mordet som politisk og religiøst motivert handling. Spørsmålet er om dette er en misbruk av ordet «hellig», enn si en vanhelligelse av offeret.

Uansett hvordan en bedømmer fenomenet, vil bare det at det forekommer en slik form for institusjonalisert selvmord i religiøs kontekst prege vår lesning av beretningen fra Genesis 22 og av Frygt og Bøeven. Det skjer uvilkårlig og nødvendiggjør en anakron lesning av tekstene. ${ }^{22}$ Dette er nemlig tekster som ikke bare leses av ettertiden, men som til de grader bidrar til å forme sin ettertid. Vi befinner oss altså allerede innenfor denne teksten når vi vender blikket mot fundamentalismen i det 2I. århundre.

Felles for Johannes de Silentio og, la oss si, Mohammed Atta, er gjentagelsen av et abrahamittisk offer i en moderne tid. Mohammed Atta trakk selv en slik parallell til Abrahams ofring av Ishmael i avskjedsbrevet til ettertiden. ${ }^{23}$ Det som dessuten forbinder dem er nødvendigheten av å være taus frem mot utførelsen av offeret, for de kan ikke tale. Taler de om sitt forehavende, ødelegger de muligheten av et offer. Derfor er begge nødt til å tale uten å tale og handle i ubetinget lydighet uten å røpe sitt forehavende til noen utenforstående. En forskjell - og dette kan vise seg å være en avgjørende forskjell - er at Atta ofrer seg selv, mens de Silentio vektlegger offeret av sønnen. Betydningen av offeret hos sistenevnte skjerpes nettopp fordi det skjer innenfor en kjærlighetsrelasjon; faderens kjærlighet til sønnen - eller mannens (Søren K.) kjærlighet til kvinnen (Regine Olsen). Selvmordet som offer kan i hvert fall ikke på samme måte innordnes i en slik kjærlighetsrelasjon og stiller seg derfor også noe annerledes i forhold til gavens økonomi.

Atta vil neppe stå tilbake for de Silentio når det gjelder lidenskap, heller ikke med hensyn til hengivelse. Og nettopp dette er vi nødt til å anerkjenne hos Atta, konflikten mellom en høy moral innenfor et gitt moralsk system og de fatale følgene av hans offerhandling, hans dødelige gave til samtiden idet han overtar kontrollen over flyet og styrter det inn i et av de to tårnene. Den sterke moralske fordømmelsen fra vestlige samfunn, formulert gjennom presidentens munn, er der- 
for fullt forståelig, men for en mer dyptgående analyse likevel utilstrekkelig. Resultatet blir en konflikt mellom ulike moralske systemer, basert på prinsipper som er inkommensurable og i siste instans begrunnes ut fra religiøse absolutter. På begge sider foregår det en teleologisk suspensjon av det (allment) etiske med henvisning til at en befinner seg i en unntakssituasjon. Hver selvmordsbomber og hvert offer (victim) for bomben, i likhet med hver torturert fange og hvert «uskyldig» sivilt offer (victim) for krigen mot terror, legitimeres med de offer (sacrifice) som kreves ut fra ens absolutte forhold til det absolutte.

Denne situasjonen stiller uvilkårlig både Kierkegaard og de Silentio i et uheldig og problematisk lys og jeg kommer ikke til å gjøre noe forsøk på å «redde» dem. Tvert imot er dette åpenbart en av de svake sidene ved både Kierkegaards og Derridas etikk, at den er for subjektiv og for lite entydig til å motstå trykket fra autoritære (enten det så er fundamentalistiske eller totalitære) religioner og ideologier. Konflikter som begrunnes ut fra absolutte posisjoner krever en intersubjektiv begrunnelse basert på en antatt universell gyldighet som massiv motvekt. ${ }^{24}$

På den annen side står også mer universelle ansatser innenfor moralfilosofien alltid i fare for å misbrukes av et system. Et eksempel på dette er Tyskland på 30tallet, der arven etter den kantianske pliktetikk og den hegelske Sittlichkeit inngikk i en strategi for å styre det tyske folk ut fra dets forpliktelse til å kjempe for folk og ferdeland. Nettopp ved hjelp av en grundig internalisert etikk fundert på humanistiske idealer ble det tyske folk til Hitlers villige håndlangere. ${ }^{25}$ Det som både før og siden har vært ansett for en sivilisert og høyverdig etikk ble brukt målrettet for å giøre kampen mot «de andre» (jøder, bolsjeviker etc.) mer effektiv. Som korrektiv til en slik systematisk utnyttelse av en moralsk forpliktelse er det muligens kun den enkeltes absolutte ansvar som vil kunne yte en kvalifisert motstand. Uten sammenligning for øvrig reiser Kierkegaard også en anklage mot samtidens etablerte kristendom for å representere et gjennomført bedrag - som nødvendiggjør en kamp mot «det allmenne». Lokaliseringen av de Silentios overveielser er derfor ikke i sentrum av etikken, men i analysen av etikkens randsoner, i unntakssituasjonen som så i kraft av å være unntak eller suspensjon også setter hele det etiske system i et annet perspektiv. Suspensjonen vil ikke kunne erstatte etikken eller den allmenne etiske refleksjon, snarere fungerer den i ethvert henseende som et supplement og et paradoksalt overskudd (fr. «surplus»). Nettopp derfor angår den imidlertid også noen av etikkens religiøse forutsetninger - enten disse av filosofien oppfattes som relevante eller ikke. Et samlende stikkord for disse forutsetningene er «kjærlighet», som for enkelte moralfilosofer vil lyde perifert og irrelevant for etikken, men som i vår sammenheng står helt sentralt. 
I det øyeblikk kjærligheten ikke lenger er abstrakt, men skal uttrykkes i handling, innhentes den av offeret som sitt særlige dilemma. En kunne si at nestekjærlighetens dilemma er nettopp dette at den uvilkårlig fører med seg et offer. Offeret er ikke et mål i og for seg, men en konsekvens. Når offeret ikke lenger springer ut av kjærligheten som overordnet mål, blir den en avansert form for kynisk idealisme, eller for å si det med apostelen; «drønnende malm og klingende bjelle» (I Kor I3,I). Det er dette Ibsen har sett i en av sin yndlingsskikkelser, den store forkynneren og idealisten Brand. For en fjernt utenforstående synes faktisk noe lignende å være tilfelle med Mohammed Atta. Det er den manglende kjærligheten som gjør at jeg ikke bare ikke kan forstå ham - slik jeg heller ikke forstår Abraham - men heller ikke kan se noe stort over hans heltemot. Hadde hans indre konflikt, som han må ha utkjempet i det stille, røpet noen tegn på en skjult kjærlighet, ville selv hans fatale offer ha hatt menneskelige trekk, den kunne ha hatt noe stort over seg - slik også en væpnet kamp for frihet mot en tilsynelatende uovervinnelig overmakt gjerne har sterke og motsetningsfylte menneskelige trekk. Men ut fra det vi har fått kjennskap til om Mohammed Atta, er hans offerhandling et resultat av en tro uten kjærlighet, dvs. kjærlighetens lidenskap fins her kun under motsatt fortegn, som et intenst hat mot «de andre». Hans fundamentalisme fremstår derfor som et lett bytte for en «økonomisk» utnyttelse av offeret i en gjensidig utveksling av frykt (dvs. terror) mellom muslimer, jøder og kristne. Kanskje er dette hva en kan kalle fundamentalisme proper, som i realiteten vel så mye er et barn av den moderne tid som av en «opprinnelig» religiøs impuls.

Det er neppe kontroversielt å påpeke at ulike gudsforestillinger spiller en viktig rolle for selvmordsbombing og annen religiøst motivert terror. Selvmordet springer ut av offerets økonomi, men predikantene og de militære strategene misbruker den tradisjonelt hellige offerhandling ut fra veloverveide religiøst-politiske interesser. I en viss forstand kan det synes som om også offerhandlingen profaniseres og sekulariseres. Selvmordsbomberen blir ved sin voldelige død uttrykket for at selv fundamentalismen må kapitulere for det sekulære vestlige samfunn den kjemper mot; han kapitulerer nemlig for den moderne rasjonalitet som han så intenst hater. Også i denne forstand er den religiøse fundamentalismen et barn av moderniteten og er i kampen mot det moderne dypt forviklet i modernitetens ekstremisme og totalitarisme, slik denne har kommet til uttrykk både i ønsket om «Endlösung», i drømmen om det kommunistiske idealsamfunn og til stadighet forkynnes i markedets hellige ubiquitet. 


\section{Dobbeltbevegelsen og gjentagelsens problem}

Kjærligheten forholder seg faktisk ikke entydig til spørsmålet om den enkeltes forhold til det allmenne, evt. forholdet mellom partikularisme og universalisme, som opptok Roe Fremstedal. Det universelle utelukker slett ikke det partikulære, det er nettopp i forhold til kjærligheten det her oppstår både spenning og konflikt. Selv om nestekjærlighetsbudet er et kall om å elske enhver (dvs. har allmenn gyldighet), så er det et bud som er rettet mot den enkelte - og den enkelte i vedkommendes forhold til den annen som fremmed, ukjent eller annerledes. Den særlige dreiningen i spørsmålet til den skriftlærde (Luk IO, 36-37) viser tydelig hvordan kjærligheten fikserer den enkelte i ethvert forsøk på å unndra seg kjærlighetens kall med en henvisning til den allmenne etikk. Konkretiseringen av kallet forutsetter nettopp at den enkelte ser seg selv som en neste, som den annen, og setter den som trenger til kjærlighet i sentrum for oppmerksomheten. Det er også hemmeligheten i Jesu ord om å miste seg selv for å finne seg selv (Luk 9, 24). Det er en bevegelse i dette kallet som roper en ut fra ego- og logosentrismen og hen mot den annen; mot det annet menneske og Guds definitive annerledeshet. Det er et slikt kall som sprenger den økonomiske gjensidighet i gavens logikk. Den mellommenneskelige gjensidighet brytes opp og dekonstrueres av gaven som overstrømmende godhet, uten hensyn til den giensidige egennytten (qua eudaimonia eller utilitas) som etisk grunnprinsipp og «regulativ idé».

Det er her konfliktene oppstår: For det første konflikten med den selvkjærlighet som realistisk sett må forutsettes. ${ }^{26}$ For det andre konflikten mellom kjærligheten og offeret, at den som en elsker iblant også er den som en ofrer. Selv om en motsetter seg offeret og helst vil unndra seg konflikten det reiser, så er denne konflikten nærmest uunngåelig (Derrida 2005: 4I). I Abrahams intensjon om å ofre sønnen Isak, i lydighet mot et kall han ikke kunne avvise, konsentreres mange av disse konfliktene. Det er konflikten mellom kjærligheten til Gud og kjærligheten til en sønn; det er bruddet med det allmenne som tvinger Abraham til taushet; og det er hans villighet til å ofre sønnen som ifølge tradisjonen ikke bare uttrykker hans mot, men også hans troskap og rettferdighet. De Silentio kan følge Abraham så langt som til selvoppgivelsen og resignasjonen på seg og sitt. Men det han ikke er i stand til å følge, er hans antatte tro på å få sønnen tilbake $i$ dette liv - på tross av forstanden. Tilliten til det umulige - at for Gud er alt mulig, som uforutsett gave og overstrømmende godhet - denne uendelige dobbeltbevegelse er det han ikke er i stand til å følge, ikke er i stand til å gjenta etter Abraham. For øvrig er det også dette Kierkegaard selv har vanskeligheter med i forholdet til Regine: Han kan resignere på alt sitt, men han er ikke i stand til å tro at han skal få hele virkeligheten tilbake. Det er dette som er det inkommensurable ved Abraham, den motsigelse og 
det unntak som de Silentio beundrer, men ikke kan fatte annet enn «i kraft af det Absurde».

Dobbeltbevegelsen står sentralt også i Derridas lesning av Frygt og Bæeven. Det dreier seg om gjentagelsens problem: Hvordan er det mulig å gjenta Abrahams absolutte avgiørelse uten at man griper til kniven og ofrer sin sønn, enten det nå skjer på Morija berg eller på Montmartre? (Sml. Derrida I995: 85) Hele problemstillingen synes å hvile på en form for fundamentalisme, men i dette tilfelle en fundamentalisme som etablerer en ubetinget forpliktelse overfor den annen. Det påfallende med denne fundamentalismen er at den ikke kan berope seg på Skriften annet enn i indirekte forstand. Ingen kan gjenta Abrahams offer uten å begå en tragisk forbrytelse, men enhver er kalt til å gjenta Abrahams offer i kallet til ubetinget ansvar overfor den annen. Dermed forutsetter denne formen for fundamentalisme paradoksalt nok et brudd med fundamentalismen i betydningen biblisisme eller blind lydighet mot Skriften. Vi kunne gi dette en typisk derridask dreining: Fundamentalisme uten fundamentalisme, ja faktisk en fundamentalisme uten fundament. ${ }^{27}$

Fundamentalismen i dens moderne form forsøker å etablere Skriften, åpenbaringen eller tradisjonen som uanfektet fundament for troens rasjonalitet - og med utgangspunkt i dette fundamentet å utelukke enhver uønsket side ved det moderne, enten det moderne uttrykkes ved liberal seksualmoral, ved et bart kvinnehode, ved kvinnelige prester, ved homofilt ekteskap eller ved et demokratisk styringssett. Det er dette urokkelige fundamentet fundamentalismen baserer sin modernitetskritikk og sin totalitære kamp mot det moderne på. Men den Gud som kaller på Abraham er ikke tilgjengelig som «fundament», kun som den absolutt ansvarliggjørende andre. Bak avgrunnen og etikkens sammenbrudd håper og tror Abraham på en Gud som er god, som er all godhets og kjærlighets kilde. Det er nettopp denne tillit til Guds godhet som muliggjør offeret, ja, nødvendiggjør offeret $\mathrm{i}$ troens uendelige dobbeltbevegelse. Fundamentet er borte, det er rystet og dekonstruert nettopp av dette uendelige som unndrar seg forstandens kontroll.

Det er således forholdet til den annen som absolutt annen som for Derrida dekonstruerer Skriften som etisk system, slik også Kierkegaard synes å ville dekonstruere det hegelske system for «Sittlichkeit» med utgangspunkt i et absolutt forhold til det absolutte. Henvendelsen til samvittigheten synes i begge tilfeller å være i overensstemmelse med Kants kategoriske imperativ, men det absurde i avgjørelsens øyeblikk markerer et brudd med forsøket på å rasjonalisere og systematisere den praktiske fornuft. Angsten og tvilen blir hos de Silentio uttrykk for fornuftens kroniske tvil på den sannhet den setter sin lit til: 
Naar galt skal være, saa er dog en Tvivler, om han end ved at tale bragte al mulig Ulykke over Verden, langt at foretrække for disse elendige Slikmunde, der smage paa Alt, og som ville helbrede Tvivlen uden at kjende den, og som da derfor i Almindelighed ere den nærmere Anledning til, at Tvivlen bryder vildt og ustyrligt frem. (...) Kan Tvivleren derimod blive den Enkelte, der som den Enkelte staaer i et absolut Forhold til det Absolute, saa kan han faae en Bemyndigelse for sin Taushed. I saa Fald maa han gjøre sin Tvivl til Skyld. I saa Fald er han i Paradoxet, men i saa Fald er hans Tvivl helbredet, om han end kan faae en anden Tvivl. (SKS 4: 199)

Tvileren som står i et absolutt forhold til det absolutte er en gjentagelse av den metodiske tvil hos Descartes (et gjennomgangstema i Frygt og Boeven), men denne gang med henblikk på etikken istf. metafysikken. Descartes' metodiske tvil fører ham inn i en epistemologisk fundamentalisme eller «foundationalism»: Enhver erkjennelse er usikker og må forkastes bortsett fra den som kan føres tilbake på cogito-erkjennelsens ubetingede visshet. ${ }^{28}$ I et av sine første essay har imidlertid Derrida påpekt at også cogito forblir en anfektet erkjennelse. Den vil aldri kunne tjene som sikkert og ubetvilelig fundament for metafysikken. Den anfektes gang på gang av galskapens mulighet, av muligheten for at verden styres av en ond genius. Og tvilen overvinnes kun ved tilliten til at cogito ikke utelukker, men omfatter selv den gale i hans eller hennes galskap: «Je ne philosophe que dans la terreur, mais la terreur avouée, d'être fou» (Derrida 1967b: 96). Filosofi er altså en tenkning omkring grensen mellom galskap og forstand - og ikke en totalitær grensedragning - nettopp fordi forstanden ved tvilen er blitt seg sin begrensning og utilstrekkelighet bevisst.

Også for de Silentio blir Descartes' tvil eksemplarisk fordi den ikke tar erkjennelsen for gitt, slik han selv ikke tar etikkens premisser for gitt. Abraham representerer et moteksempel. Med ham står hele etikken som allment og gjennomsiktig system på spill. Selv om ofringen må avvises av den allmenne etikk, så følger Abraham sitt kall. Han står helt og holdent ansvarlig fremfor Gud og kan ikke lette sin samvittighet ved å diskutere kallet med sin familie eller sine venner.

I avgjørelsen står således den enkelte ansvarlig også om en handler på tross av etikkens normer. Den grunnleggende tvilen finner ikke noe definitivt opphør i en cogito- eller credo-erkjennelse som gjør det mulig å slutte fra en klar og selvinnlysende sannhet til logiske konsekvenser. Det er snarere med tvilen som forutsetning og i tvilerens resignasjon at en ubetinget tillit gir den impuls som skal til for å handle. Igjen står vi altså ved «Uendelighedens Dobbeltbevegelse»: Den uendelige resignasjon, den totale tvil, slås tilbake av en ubetinget (og derfor «uendelig») tillit, selve forutsetningen for også å handle - i kraft av det absurde. Den grunnleggende tvilen på offerets nødvendighet betyr altså ikke at de Silentio, enn si Der- 
rida, motsetter seg møtet med den annen som absolutt annen. Tvert imot, i denne forstand søker de like til opphavet, til den uutgrunnelige autoritet forut for enhver handling. Men det er en skjult annen, en annen som unndrar seg min kontroll, og som $i$ etisk forstand møter meg i ansiktet, det menneskelige ansiktets transcendens. Stilt overfor den annen, som i sin annerledeshet åpner både for gjenkjennelsen og det absolutt annet, vil ethvert menneske måtte skjelve - i frykt og beven.

Om en derimot ikke skjelver, om en ikke en gang tviler på handlingens legitimitet, er det neppe et tegn på mot eller etisk dømmekraft, snarere på overflate. Mangelen på uro kan en gjenfinne i den fundamentalisme som ikke ser lydigheten mot Gud som en etisk suspensjon, men som leser Bibelen som ufeilbarlig verbalinspirasjon, som altså suspenderer tvilen med henvisning til den hellige skrift. En slik selvsikkerhet springer ut av et gudsbegrep som erstatter avgrunnens frykt og beven med et bestemt, stabilt tegn i det språklige system: Navnet «Gud». Et slikt språklig tegn kan uten større vanskeligheter operasjonaliseres og instrumentaliseres. Vanskeligere er det å gjøre noe tilsvarende med et mysterium tremendum.

Nettopp derfor er det så viktig at Frygt og Bæeven verken underlegges en idealistisk eller en modernistisk rasjonalitet slik hhv. Hösle og Fremstedal forsøker på. Det er denne type rasjonalitet forfatteren kjemper mot med fortvilelsens kraft. Det er her, i fundamentet eller fundamentalismen som hefter ved modernitetens og idealismens rasjonalitet selve rystelsen finner sted. Her er det tvilen skal slå inn og slå sprekker for å gjøre den enkelte ansvarlig - som enkelt.

Slik Kierkegaard ser det, er det nettopp i betegnelsen, i henvendelsen, i oversettelsen og i handlingen at tvilen uvilkårlig giør seg gjeldende. Den grunnleggende tvil på hvem en har med å gjøre, om det er en bestemt annen, om navnet på denne annen skal oversettes slik en selv tror, om handlingen blir stående for rettferdighetens dom, for blikket som ser uten selv å bli sett (jf. Derrida I995: 9I-92). Det dreier seg altså ikke bare om den første tvil, slik vi finner den hos Descartes. Det dreier seg også om en annen tvil, en tvil som henger sammen med en prinsipiell uvisshet, og som i enhver senere gjentagelse av Abrahams tro initierer en handling i kraft av paradokset.

I hjertet av troen som «tradisjon» som gis videre fra generasjon til generasjon ligger også en slik «traduction» eller «translation», et forsøk på å formidle en uutgrunnelig hemmelighet, et forsøk på å tale om det uutsigelige (SKS 4: 20I; Derrida I995: 79-80). Dersom Abrahams offer skal få noen betydning i forhold til troen på Abrahams Gud, er det i kraft av en slik gjentagelse i hver ny generasjon, som ikke kan tilegnes annet enn i frykt og beven overfor det ukjente. I dette siste er det intet som skiller et moderne menneske fra Abraham i møtet med det uutgrunne- 
lige, en Gud som kaller og som prøver, som stiller til ansvar - men som overlater ansvaret til den enkelte, til den enkelte som enkelt, i taushet. Dette absolutte ansvaret overfor den annen kan ikke begrunnes rasjonelt, og det er ifølge Derrida det skremmende med et slikt mysterium tremendum innskrevet i den menneskelige virkelighet: Dette at ethvert ansvar må føres tilbake på forholdet til den annen, men at det krever en avgjørelse av hver enkelt som ikke kan giøres allmenn - og dermed heller ikke fullt ut språkliggiøres og rasjonelt forklares med «tre Grunde». Kjærlighetens opphav forblir skjult, selv når den på tross eller på grunna av offeret gjenkjennes som kjærlighet.

For ordens skyld vil jeg understreke at Derrida, i likhet med Kierkegaard, forutsetter at gyldige etiske begrunnelser og generelle etiske prinsippene både kan og skal artikuleres og derfor så vidt mulig skal gjøres eksplisitt. Men den grunn selve avgjørelsen springer ut av kan ikke uttrykkes i generelle termer; ansvaret må forutsettes som gitt og finner hver gang et nytt uttrykk i en ny situasjon, i møtet med den annen. Derrida og Kierkegaard samstemmer derfor i dette at de ser Abrahams ansvar som eksemplarisk for ethvert møte med den annen - den absolutt annen så vel som enhver annen annen. På den ene side er det derfor visse ting ved dette møtet, ved ansvaret for den annen som kan forklares, som kan begrunnes og redegjøres for, men på den annen side er det visse ting ved dette møtet, ved ansvaret for den annen, som ikke kan forklares, som tvert imot hører tausheten til og formidles som hemmelighet, som en taus avgjørelse - slik det skjer i forhold til offeret, slik det skjer i forhold til gaven.

Noter

I For alle henvisninger til verk av Kierkegaard siterer jeg fra den siste kritiske utgaven av verkene: N.J. Cappelørn et al. (utg.), Søren Kierkegaards Skrifter [SKS] (København: Gads forlag I997 ff.).

2 Dette er en form for kritikk som kan føres helt tilbake til Georg Brandes, men Fremstedal legger særlig vekt på innvendingene fra den tyske filosofen Vittorio Hösle, som kritiserer Kierkegaard fra en uttalt hegelsk posisjon. Hösle er elev av Karl-Otto Apel, som fastholder sannhetens transcendentale begrunnelse innenfor den kritiske teori. Hösle selv er en av de svært få som fullt ut forsvarer en høyrehegeliansk etikk i Tyskland i dag (Hösle I997). Dette hegelske ut- gangspunktet preger også hans kritikk av Kierkegaard, men gjør den ikke mindre aktuell.

3 Patriarken får sannelig sitt pass påskrevet, som i følgende formuleringer: «Antagelsen av en ufeilbarlig åpenbaring fører til at Abraham blir en absurd, isolert og taus skikkelse som tenker fundamentalistisk og paternalistisk.» (Fremstedal 2006: IOO-IOI)

4 Dessuten kritiserer Kierkegaard (under pseudonymet Johannes Climacus) i Efterskriften også sitt eget pseudonym Johannes de Silentio. (Fremstedal 2006: 90)

5 Den lange rekken av Kierkegaard-kritikere omfatter blant annet prominente navn som Brandes, Høffding, Adorno, Buber, 
Bohlin og Hösle. (Fremstedal 2006: 88; 90)

6 Denne problematikken er behandlet mer utførlig i avhandlingen Autopsi (Mjaaland 2005: II7-I29).

7 I lojalitet til Kierkegaards uttrykte ønske i Efterskriften refererer jeg stort sett til Johannes de Silentio som forfatter av boken. I diskusjon av hele forfatterskapet blir dette imidlertid mer tungvint og jeg forholder meg da til Søren Kierkegaard som den forfatter som de jure bærer ansvaret for tekstene - og som tross alt har ført det hele i pennen.

8 Således skriver Kant i Der Streit der Fakultäten: «Abraham hätte auf diese vermeinte göttliche Stimme antworten müssen: 'Daß ich meinen guten Sohn nicht tödten solle, ist ganz gewiß; daß aber du, der du mir erscheinst, Gott sei, davon bin ich nicht gewiß und kann es auch nicht werden', wenn sie auch vom (sichtbaren) Himmel herabschallte.» (Kant I968b: 73 (note)). I Religion innerhalb der Grenzen der bloßen Vernunft skriver han: «Daß aber Gott diesen fürchterlichen Willen jemals geäußert habe, beruht auf Geschichtsdocumenten und ist nie apodiktisch gewiß. Die Offenbarung ist ihm doch nur durch Menschen zugekommen und von diesen ausgelegt, und schiene sie ihm auch von Gott selbst gekommen zu sein (wie der an Abraham ergangene Befehl, seinen eigenen Sohn wie ein Schaf zu schlachten), so ist es wenigstens doch möglich, daß hier ein Irrthum vorwalte.» (Kant I968a: I87). Se også Hegel i992.

9 For en tenker som Hösle er dette umulig av prinsipielle grunner. Han motsetter seg den rasjonalitet som Kierkegaard tar til orde for - og det er en redelig sak. (Hösle I992: 8-I6) Noe mer problematisk er det med hans forsøk på å «redde» Kierkegaard tross alt og da gjennom en dialektisk syntese med Hegel. (Hösle I992: 20-24) Io Se fremfor alt den hengivne gravtalen
Adieu til vennen og læreren Levinas: Derrida 1997.

II Mon ikke selve utgangspunktet for å stille et slikt problem ville virke temmelig paternalistisk i våre dager? Det er i hvert fall lite som tyder på at likestilling mellom kjønnene sto i forgrunnen.

I2 Levinas' lesning er på dette punktet svært omstridt, selv blant dem som ellers sympatiserer med hans posisjon, som f.eks. den dansk-jødiske fortolker Klaus Wivel. Han er ytterst kritisk til Levinas' fortolkning av Frygt og Baven i en bok hvis tese baserer seg på Levinas' og Rosenzweigs kritikk av Kierkegaard: «Men Abraham allegoriserer en indre ofring, en selvtilintetgørelse, og Lévinas tager derfor fejl, når han lader Kierkegaard retfærdiggøre en utvendig suspension af det ethiske. I den forstand er der intet forvarsel om Nationalsocialismen at spore hos den danske tænker.» (Wivel ı999: пा6)

I3 «Dans ce sens, le sacrifice pour autrui créerait avec la mort de l'autre un autre rapport: responsabilité qui serait peut-être le pourquoi l'on peut mourir. Dans la culpabilité de survivant, la mort de lautre est mon affaire. Ma mort est ma part dans la mort d'autrui et dans ma mort je meurs cette mort qui est ma faute.» (Levinas I993: 49)

I4 Først holdt som et foredrag i I992. Her refereres til den engelske oversettelsen fra I995. Jeg skylder å gjøre leseren oppmerksom på at denne og neste del av artikkelen i noen grad baserer seg på min prøveforelesning for doktorgraden på Teologisk Fakultet 09.12.2005.

I5 Se Derrida I995: 82-84. Sml. også s. 88: «We have here a kind of shibboleth, a secret formula such as can be uttered only in a certain way in a certain language. As a chance or aleatory effect, the untranslatability of this formal economy functions like a secret within one's so-called natural or mother tongue.» 
I6 Kierkegaard argumenterer for en slik bestemmelse av forholdet mellom en selv og nesten i Kjerlighedens Gjerninger: «Næsten er da Dig nærmere end alle Andre. Men er han Dig ogsaa nærmere end Du er Dig selv? Nei, det er han ikke, men han er just, eller skal just være Dig lige saa nær.» (SKS 9: 29)

I7 «La différence inouie entre l'apparaissant et l'apparaître (entre le 'monde' et le 'vécu') est la condition de toutes les autres différences, de toutes les autres traces, et elle est déjà une trace. Aussi ce dernier concept est-il absolument et en droit 'antérieur' à toute problématique physiologique sur la nature de l'engramme, ou métaphysique sur le sens de la présence absolue dont la trace se donne ainsi à déchiffrer. La trace est en effet l'origine absolue de sens en général. Ce qui revient à dire, encore une fois, qu'il n' $Y$ a pas d'origine absolue du sens en général. La trace est la différance qui ouvre l'apparaître et la signification.» (Derrida I967a: 95)

I8 Selve påstanden om at en åpenbaring er tilgjengelig som «absolutt bevissthetsfaktum» synes noe malplassert i denne sammenheng, som et forsøk på å komme til rette med ting en ikke forstår og ikke har noe adekvat begrep om. Jf. Fremstedal I996: 96.

I9 «Dog jeg vender tilbage til Abraham. I den Tid før Udfaldet var Abraham enten i hvert Minut en Morder, eller vi staae ved det Paradox, der er høiere end alle Mediationer.» (SKS 4: 159)

$20 \mathrm{Se}$ artikkelen «Fundamentalism» (a) i OED online: http://dictionary.oed.com

2I Jf. «Fundamentalism» (b) i OED online: http://dictionary.oed.com

22 Derrida har ved flere anledninger pekt på teksters «anakrone» karakter, som gjør at de unndrar seg kategoriseringen som enten «synkron» eller «diakron». I Gift of Death kommer han i en lignende argumentasjonsrekke inn på det ikke-presen- tiske ved avgjørelsen (Derrida 1995: 6566).

23 Cf. Derrida 2005: 40. Attas testament ble skrevet allerede i I996 og gjort kjent etter 9/II, bl.a. i magasinet Der Spiegel (I. oktober 200I). En engelske oversettelse er tilgjengelig under: http://www.pbs.org/ wgbh/pages/frontline/shows/network/ personal/attawill.html

24 I slike situasjoner vil for eksempel Habermas' kommunikative diskursetikk ha større betydning, ganske enkelt i kraft av sin fremhevning av det felles menneskelige og det medmenneskelige. Også Hegels «Sittlichkeit» og Kants kategoriske imperativ har med sine rasjonalistiske ansatser større tyngde eksempelvis i argumentasjonen for universelle menneskerettigheter. Kierkegaard og Derrida tar opp en problemstilling som befinner seg på et annet nivå, nemlig: (I) Forholdet mellom egoisme og (neste)kjærlighet - og (2) Dette at noen mennesker og noen hensyn iblant vil måtte ofres til fordel for andre.

25 Sml. f.eks. Bölls satiriske novelle «Wanderer gehst du nach Spa...» (I950) i: Böll 2006: 223-233.

26 «[Selvkjerligheden] ligger nemlig i at elske sig selv; men skal man elske Næsten 'som sig selv’, saa vrister jo Budet, som med en Dirk, Selvkjerlighedens Lukke op og fravrister dermed Mennesket den. Hvis Budet om at elske Næsten var udtrykt paa en anden Maade end med dette lille Ord «som Dig selv», der paa eengang er saa let at haandtere og dog har Evighedens Spændkraft, da vilde Budet ikke saaledes kunne magte Selvkjerligheden.» (SKS 9: 25-26)

27 Sml. uttrykket «religion uten religion», som for Derrida betegner gjentagelsen av den religiøse impuls uten de religiøse dogmer og institusjoner som gjør religionen problematisk, kan hende umulig å akseptere for et intellektuelt redelig, senmoder- 
ne menneske. (Sml. Derrida I995: 49)

28 Epistemologisk foundationalism er atskillig eldre enn fenomenet religiøs fundamentalisme. Det giør seg gjeldende i debatten mellom rasjonalister og empirister og gjelder grunnlaget for (sanse-) erkjennelse. Antagelig er denne form for «fundamentalisme» og fundamental tvil vel så godt egnet for en historisk analyse av Frygt og Baven som den moderne politisk-religiøse fundamentalisme. Analysen som her foretas gjelder snarere det motsatte, nemlig å forstå den religiøse fundamentalismen bedre med utgangspunkt i Kierkegaard.

\section{Litteratur}

SKS = Søren Kierkegaards Skrifter, N.J. Cappelørn et al, København: Gads forlag I997.

Agacinski, S., I998 «We Are Not Sublime: Love and Sacrifice, Abraham and Ourselves», i: J. Rée \& J. Chamberlain, Kierkegaard: A Crtical Reader (Oxford: Blackwell): I29-I5O.

Böll, H., 2006 Erzählungen (Köln: Kiepenhauer \& Witsch).

Caputo, J. D., I998 «Looking the Impossible in the Eye», i: N.J. Cappelørn, H. Deuser \& J. Stewart (utg.) Kierkegaard Studies Yearbook 1998 (Berlin/New York: deGruyter).

Derrida, J., I967a De la Grammatologie (Paris: Éditions de minuit).

Derrida, J., I967b L'écriture et la différence (Paris: Éditions du Seuil).

Derrida, J., I986 Glas [Overs. John P. Leavy \& Richard Rand] (Lincoln : University of $\mathrm{Ne}$ braska Press).

Derrida, J., I995 The Gift of Death [Orig. Donner la mort, overs. D. Willis] (Chicago: Chicago University Press).

Derrida, J., I997 Adieu (Paris: Galilée).

Fremstedal, R., 2006 «Forfekter Kierkegaard fundamentalisme i Frygt og Baven?» Norsk Teologisk Tidsskrift Io6: 84-I04.
Hegel, G.W.F., I992, Enzpklopädie der philosophischen Wissenschaften im Grundrisse, i : F. Hogemann \& W. Jaeschke (utg.), Gesammelte Werke, bind 20 (Hamburg: Felix Meiner Verlag).

Hösle, V., I992 «Kan Abraham reddes? og: Kan Kierkegaard reddes? Et Hegelsk oppgjør med'Frygt og Bæven'» Norsk Filosofisk Tidsskrift 27: I-26

Hösle, V., I997 Moral und Politik (München: C. H. Beck).

Kant, I., I968a, Religion innerhalb der Grenzen der bloßen Vernunft, i: Gesammelte Werke (Akademie-Ausgabe), bind 6 (Berlin: Walter deGruyter).

Kant, I., I968b, Der Streit der Fakultäten, i: Gesammelte Werke (Akademie-Ausgabe), bind 7 (Berlin: Walter deGruyter).

Levinas, E., I974 «Énigme et phénomène», i: Idem, En découvrant l'existence avec Husserl et Heidegger. 3. utg. (Paris: J. Vrin): 203-216.

Levinas, E., I993 Dieu, la mort et le temps (Paris: Éditions Grasset et Fasquelle).

Levinas, E., I996 Proper Names. [Orig. Noms Propres (1976), overs. Michael B. Smith] (London: The Athlone Press).

Mjaaland, M. G., 2005 Autopsi. Døden og synet på selvet [blant Kierkegaards aporier] (Oslo: Unipub).

Patočka, J., I979 Kjetterske studier $i$ historiens filosofi (Oslo: Aschehoug).

Stewart, J., 2003 Kierkegaard's Relations to Hegel Reconsidered (Cambridge: Cambridge University Press).

Westphal, M., I995 «The Transparent Shadow. Kierkegaard and Levinas in Dialogue», i: M. J. Matuštík \& M. Westphal (utg.), Kierkegaard in Post/ Modernity (Bloomington \& Indianapolis: Indiana University Press): 265-8I

Wivel, K., I999 Noesten intet. En jødisk kritik of Søren Kierkegaard (København: C.A. Reitzel). 